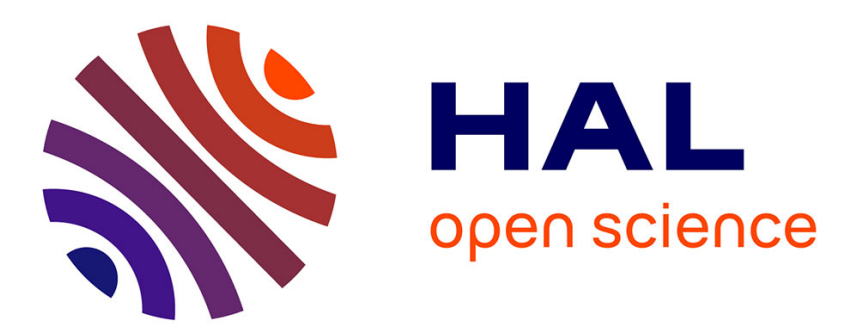

\title{
Hard coastal-defence structures as habitats for native and exotic rocky-bottom species
}

\author{
Stefano Vaselli, Fabio Bulleri, Lisandro Benedetti-Cecchi
}

\section{To cite this version:}

Stefano Vaselli, Fabio Bulleri, Lisandro Benedetti-Cecchi. Hard coastal-defence structures as habitats for native and exotic rocky-bottom species. Marine Environmental Research, 2008, 66 (4), pp.395. 10.1016/j.marenvres.2008.06.002 . hal-00501973

\section{HAL Id: hal-00501973 https://hal.science/hal-00501973}

Submitted on 13 Jul 2010

HAL is a multi-disciplinary open access archive for the deposit and dissemination of scientific research documents, whether they are published or not. The documents may come from teaching and research institutions in France or abroad, or from public or private research centers.
L'archive ouverte pluridisciplinaire HAL, est destinée au dépôt et à la diffusion de documents scientifiques de niveau recherche, publiés ou non, émanant des établissements d'enseignement et de recherche français ou étrangers, des laboratoires publics ou privés. 


\section{Accepted Manuscript}

Hard coastal-defence structures as habitats for native and exotic rocky-bottom species

Stefano Vaselli, Fabio Bulleri, Lisandro Benedetti-Cecchi

PII:

S0141-1136(08)00167-0

DOI:

10.1016/j.marenvres.2008.06.002

Reference:

MERE 3265

To appear in:

Marine Environmental Research

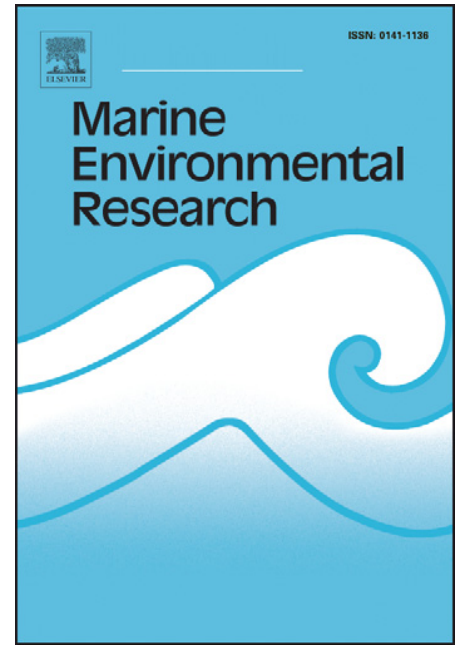

Received Date: $\quad 28$ March 2008

Revised Date: $\quad 9$ June 2008

Accepted Date: $\quad$ 11 June 2008

Please cite this article as: Vaselli, S., Bulleri, F., Benedetti-Cecchi, L., Hard coastal-defence structures as habitats for native and exotic rocky-bottom species, Marine Environmental Research (2008), doi: 10.1016/j.marenvres. 2008.06.002

This is a PDF file of an unedited manuscript that has been accepted for publication. As a service to our customers we are providing this early version of the manuscript. The manuscript will undergo copyediting, typesetting, and review of the resulting proof before it is published in its final form. Please note that during the production process errors may be discovered which could affect the content, and all legal disclaimers that apply to the journal pertain. 


\title{
HARD COASTAL-DEFENCE STRUCTURES AS HABITATS FOR NATIVE AND EXOTIC ROCKY-BOTTOM SPECIES
}

\author{
Stefano Vaselli ${ }^{\mathrm{a}, \mathrm{b}}$, Fabio Bulleri ${ }^{\mathrm{b},}{ }^{*}$, Lisandro Benedetti-Cecchi $^{\mathrm{b}}$ \\ ${ }^{a}$ Laboratory of Coastal Biodiversity, Centro Interdisciplinar de Investigação Marinha e Ambiental, \\ Rua dos Bragas, 289 - 4050-123 Porto, Portugal
}

${ }^{\mathrm{b}}$ Dipartimento di Biologia, Via A. Volta, 6, I-56126 Pisa, Italy

*corresponding author

Dipartimento di Biologia, Università di Pisa

Via Derna 1, 56126, Pisa

Italy

Tel. +390502211415

Fax. +390502211410

e-mail: fbulleri@biologia.unipi.it 
VASELLI et al.

\section{Abstract}

The use of hard coastal-defence structures, like breakwaters and seawalls, is rapidly increasing to prevent coastal erosion. We compared low-shore assemblages between wave-protected and wave-exposed habitats on breakwaters along a sandy shore of Tuscany (North-Western

5 Mediterranean). Assemblages were generally characterized by a low diversity of taxa, with space monopolized by Mytilus galloprovincialis and Corallina elongata on the seaward side of breakwaters and by filamentous algae on the landward side. Assemblages in wave-protected habitats were characterized by greater temporal stability than those in exposed habitats and supported non-indigenous macroalgae such as Caulerpa racemosa and Codium fragile ssp. tomentosoides. Hence, the introduction of hard coastal defence-structures in otherwise soft-bottom dominated areas, attracting native and exotic rocky bottom species, should be of great concern for the conservation of marine biodiversity at local and regional scales and for the management of biological invasions.

15 Keywords: Coastal zone; Artificial habitats; Coastal-defence; Wave-exposure; Biological invasions; Caulerpa racemosa; Codium fragile ssp. tomentosoides 
VASELLI et al.

\section{Introduction}

More than $60 \%$ of the human population is living in coastal zones and projections for the next decades foresee a further increase, with this fraction exceeding $75 \%$, as a consequence of the ongoing demographic expansion and tendency to migrate towards coastal areas (EEA 1999; Airoldi and Beck, 2007). The need to protect the coast from erosion and flooding have increased the use of man-made structures like breakwaters, groynes and seawalls (Bulleri, 2006; Airoldi and Beck, 2007). A further increment in the presence of hard coastal-defence structures is predicted to happen in response to sea level rise and to increases in the intensity and frequency of storms (Bray and Hooke, 1997; Valiela, 2006). Nonetheless, in contrast to terrestrial environments, artificial marine habitats have received little attention by ecologists and our understanding of their ecological value and functioning remains limited (Bulleri, 2006). Only in recent years have the importance and advantages of including ecological criteria into the design and management of man-made structure been recognized (Glasby, 1999; Glasby and Connell, 1999; Davis et al., 2002; Bacchiocchi and Airoldi, 2003; Chapman, 2003; Airoldi et al., 2005a; Moreira et al. 2007).

Much of the research in this field has been done on artificial structures deployed on hardbottoms. A number of studies has compared benthic assemblages on different types of artificial habitats (Connell and Glasby, 1998; Connell, 2001) or have assessed the extent to which artificial structures can be considered as surrogates of natural rocky habitats, focusing on assemblages of algae, invertebrates or fish (Connel and Glasby, 1998; Glasby, 1999; Davis et al. 2002; Chapman, 2003; Chapman and Bulleri, 2003; Guidetti, 2004; Chapman 2006; Clynick, 2006). To our knowledge, very few studies have instead assessed the ecological implications of introducing hard coastal-defence structures into areas where soft-bottoms are predominant (but see Davis et al., 2002, Bacchiocchi and Airoldi, 2003; Moschella et al., 2005; Pinn et al., 2005; Gacia et al., 2007). Impacts caused by their deployment have been mainly evaluated in terms of the changes caused to assemblages living in the surrounding sedimentary habitats. Changes in water flow, illumination 
VASELLI et al.

and rates of sedimentation due to the introduction of built structures can be, in fact, detrimental for plants (e.g. seagrasses) and animals living in or on soft bottom substrata (Davis et al., 1982; Barros

et al., 2001; Martin et al., 2005). Less attention has, in contrast, been given to the implications these structures may have in attracting a suite of rocky bottom organisms (Bulleri, 2005); although this function is widely acknowledged for artificial reefs that are actually built with the primary objective of functioning as aggregating devices or as tools for the rehabilitation of endangered or overexploited species (Collins et al., 1994; Carr and Hixon, 1997). Provision of hard substrata by manmade structures can facilitate the expansion of a number of hard-bottoms species, including those that are non-indigenous, in areas that otherwise lack suitable habitats (e.g. natural hard-bottoms) (Glasby and Connell, 1999; Davis et al., 2002, Bacchiocchi and Airoldi, 2003; Bulleri and Airoldi, 2005; Glasby et al., 2006), with important implications for biodiversity at local and regional scales (Bulleri, 2005).

Some types of hard coastal-defence structures, such as breakwaters, not only introduce hard substrata in otherwise sandy-dominated bottoms, but can also provide sheltered habitats along wave-exposed coasts. Wave-exposure is an important determinant of the structure of benthic assemblages (Denny, 1995). Thus, the availability of sheltered habitats can allow the development of assemblages very different from those occurring on nearby wave-exposed habitats and create, directly or indirectly, opportunities for the establishment, reproduction and spread of nonindigenous species (Bulleri and Airoldi, 2005; Bulleri et al., 2007).

At odds with the ubiquitous presence of coastal-defence schemes and with the pressing need to improve our understanding of their impacts on natural assemblages at a variety of spatial scales and of their role as surrogates of natural rocky habitats (Bulleri, 2006), very few studies (Bacchiocchi and Airoldi, 2003; Moschella et al., 2005; Pinn et al. 2005; Gacia et al., 2007) have 
VASELLI et al.

investigated patterns of distribution of epibiota they support and, in particular, assessed differences between wave-exposed and wave-sheltered habitats (Davis et al., 2002).

70

This study, by assessing patterns of abundance and distribution of epibiota on breakwaters along sandy stretches of coastline in Tuscany (NW Mediterranean), is an attempt in that direction. Specifically, we tested the hypotheses that low-shore assemblages would differ between the landward (wave-sheltered) and the seaward (wave-exposed) side of breakwaters. The generality of

75 patterns was evaluated by making these comparisons on four occasions, over a period of 15 months. Furthermore, because knowledge about the stability of assemblages, either in space or time, is important to predict the susceptibility of assemblages to the establishment of exotic species (Davis et al., 2000), we tested the hypothesis that temporal and spatial variation of the assemblages would be different between the landward and the seaward side of breakwaters.

\section{Methods}

\subsection{Study site}

The study was done on hard coastal-defence structures at Marina di Pisa, about $14 \mathrm{~km}$ north of Livorno, Tuscany (Italy), in the North Western Mediterranean (Fig. 1). The coast is sandy, exposed to westerly winds and extends from the mouth of the Arno River for about $15 \mathrm{~km}$ south.

During the mid Sixties', several offshore breakwaters running parallel to the coast were deployed to prevent the erosion of sandy shores. These are about $200 \mathrm{~m}$ in length and are made of granite blocks of irregular shape (major axis varying between 2 and $3 \mathrm{~m}$ ). Breakwaters extend about 2-3 m below the Mean Low Water Level (hereafter MLWL), are between 30 and $50 \mathrm{~m}$ offshore and separated by

90 narrow channels, about $5 \mathrm{~m}$ in width (Fig. 1). The spatial arrangement of breakwaters creates a calm internal water body on the landward side, characterized by soft bottoms and highly frequented by people from May to October (authors' personal observation). 
VASELLI et al.

\subsection{Sampling Design}

In October 2006, we started a preliminary survey to assess patterns of distribution and abundance of algae and invertebrates present on breakwaters. Two breakwaters were haphazardly selected (100s of m apart) along $2.5 \mathrm{~km}$ of coastline. Both the landward (wave-sheltered) and the seaward (wave-exposed) sides of breakwaters were sampled at low-shore levels (between 0 and 0.3 $\mathrm{m}$ below the MLWL). Three areas (about $5 \mathrm{~m}$ long and 10s of $\mathrm{m}$ apart) were then randomly selected within each side of each breakwater. The cover of sessile organisms and bare rock was quantified visually in five randomly placed $20 \times 20 \mathrm{~cm}$ quadrats in each area, subdivided into 25 sub-quadrats ( 4 x $4 \mathrm{~cm})$. A score from 0 to $4 \%$ was given to each taxon in each sub-quadrat and the percentage cover was obtained by summing over the entire set of sub-quadrats (Dethier et al., 1993). When possible, organisms were identified in the field to species or genus; when it was not possible, taxa were lumped into morphological groups (Steneck and Dethier, 1994).

In December 2006, a greater number of breakwaters was included in our sampling design in order to improve our ability to estimate variation in assemblages at this spatial scale (i.e. among breakwaters). Thus, four breakwaters were randomly selected from a larger number available and, on each of these, two areas (about $5 \mathrm{~m}$ long and 10s of $\mathrm{m}$ apart) were randomly identified on both the landward and the seaward side. Different areas were selected for each time of sampling (December 2006, May and October 2007), to ensure data independence (Underwood, 1997). Within each area, low-shore assemblages were sampled in five replicate quadrats with the same procedures previously described.

\section{$115 \quad 2.3$ Data analysis}

To test for differences in the structure of assemblages between exposures, data from the first time of sampling (October 2006) were analysed by permutational multivariate analysis of variance (PERMANOVA, Anderson, 2001). The analysis included the following factors: (i) Exposure, fixed, 2 levels (landward and seaward side of breakwaters); (ii) Breakwater, random, 2 levels, crossed 
VASELLI et al.

with Exposure; (iii) Area, random, 3 levels, nested within the interaction of the other factors.

Student's $t$-test was used for multivariate pair-wise a posteriori comparisons.

Multivariate patterns were displayed graphically by plotting the centroids of areas in a nMDS (non-metric Multidimensional Scaling) based on Euclidean distances. In order to obtain centroids of each area for each date of sampling, we first calculated a dissimilarity matrix based on the BrayCurtis index among all the observations. Because Bray-Curtis is a semi-metric index, centroids cannot be obtained simply as arithmetic averages of these dissimilarities (Anderson 2001). Thus, we first calculated principal coordinates from the Bray-Curtis dissimilarity matrix. This places the observations into a Euclidean space without altering the Bray-Curtis measure: i.e. the distance between any pair of observations based on the principal coordinates is equivalent to the dissimilarity between those observations obtained from the original variables. Centroids were then obtained as arithmetic averages of the principal coordinates over the 5 replicates of each area in each date of sampling.

The abundance of common taxa were analysed with analysis of variance (ANOVA), following the same design used for the PERMANOVA. Prior to analyses, Cochran's $C$ test was used to assess the assumption of homogeneity of variances and data were $\operatorname{Ln}(x+1)$-transformed, if necessary (Underwood, 1997). Student - Newman - Keuls (SNK) tests were used for pairwise a posteriori comparisons of means.

Data from the subsequent three times of sampling were analysed with the same multivariate and univariate techniques, but with a slightly different design. This included the following factors: (i) Date, random, 3 levels; (ii) Breakwater, random, 4 levels, crossed with Date; (iii) Exposure, fixed, 2 levels (landward and seaward side of breakwaters), crossed with both Date and Breakwater; (iv) Area, random, 2 levels, nested within the interaction of the other factors. Furthermore, SIMPER 


\section{VASELLI et al.}

analysis (Clarke, 1993) was used to identify those taxa that most contributed to Bray-Curtis dissimilarities between the seaward and landward sides of breakwaters at each date of sampling.

Univariate methods for partitioning variation among factors have been successfully extended 150 to multivariate data, providing new insights into assemblage heterogeneity in marine environments (Terlizzi et al. 2007). Estimates of temporal variation in structure of assemblages were obtained by running a 2-way PERMANOVA including the factors Time (random, 3 levels) and Area (random, 2 levels and nested in Time), separately for each combination of breakwater and wave-exposure. The multivariate pseudo-variance components for each term in the model were then calculated using multivariate analogues to the univariate ANOVA estimators (e.g. Searle et al. 1992, Terlizzi et al. 2007). Observed mean squares were equated to the expected mean square derived from the linear model of the analysis (Underwood, 1997). This procedure generated a total of 8 replicate measures of temporal variation, 4 for each of the seaward and the landward sides of breakwaters. Estimates of spatial variation between areas were obtained using a similar procedure; for each date of sampling, a 1-way PERMANOVA was performed for each breakwater and wave-exposure, providing 4 measures of spatial variation between areas for each side of breakwaters. Occasionally, negative estimates of pseudo variance were obtained. In these cases, variances were set to zero, assuming that they were sample underestimates of small or zero variances (Searle et al., 1992; Underwood, 1996).

\section{Results}

The multivariate analysis on data collected in October 2006 showed significant differences in the structure of assemblages between the landward and the seaward side of breakwaters (Table 1). In the nMDS, symbols representing assemblages on the landward side were segregated from those representing assemblages on the seaward side of breakwaters (Fig. 2). 
VASELLI et al.

Although there was a marked trend for the cover of Mytilus galloprovincialis and Corallina elongata, to be greater on the seaward than on the landward side of breakwaters, the ANOVAs failed to detect significant effects of wave-exposure, likely due to the lack of power of the relevant test and to heterogeneity of variances (Table 2, Fig. 3A and B respectively). In contrast, the covers of filamentous algae and Caulerpa racemosa and the amount of bare rock were significantly greater on the landward than on the seaward side of breakwaters (Table 2, Fig. 3C, D and E respectively), while the cover of encrusting corallines did not vary according to wave-exposure (Table 2, Fig. 3F). All analysed taxa, excluding $C$. racemosa and $C$. elongata, showed significant variability among areas. The number of taxa was generally small and did not differ significantly between exposures (Table 2, Fig. 5).

For the three subsequent dates of sampling, when more breakwaters were included in the survey, multivariate analyses showed significant differences in the structure of assemblages between landward and seaward side of breakwaters that were consistent through time ( $t$-tests for the interaction Date x Exposure Table 3, Fig. 4). SIMPER analyses showed that these differences were consistently caused by filamentous algae, C. elongata and M. galloprovincialis, explaining together $79 \%, 75 \%$ and $70 \%$ of the differences, in date 1,2 and 3, respectively. Interestingly, in date 3 (October 2007), C. racemosa also contributed to differences between the landward and seaward side of breakwaters, explaining $11 \%$ of the differences.

Univariate analyses showed the dominance of M. galloprovincialis and C. elongata on the seaward side and, although to a different extent among sampling dates, that of filamentous algae on the landward side of breakwaters (SNK tests in Table 4, Fig. 3A, B and C). The cover of $C$. racemosa varied markedly among dates of sampling. The alga was absent in May 2007 while it was found exclusively on the landward side of breakwaters in December 2006 and in October 2007, with a greater cover at the latter time of sampling (Table 3, Fig. 3D). The cover of encrusting 
VASELLI et al.

corallines, despite largely varying through time, was greater on the seaward than on the landward side of breakwaters (Table 3, Fig. 3F), while the opposite pattern was detected for the amount of free space (Table 3, Fig. 3E). No significant differences were detected between sides of breakwaters in the number of taxa (Table 3, Fig. 5).

Visual inspection of graphs indicates that temporal variation in the structure of assemblages was greater in assemblages on the seaward side than those on the landward side of breakwaters (Fig. 6A). In contrast, variation within breakwaters, at the scale of $10 \mathrm{~s}$ of $\mathrm{m}$, did not vary according to wave-exposure (Fig. 6B).

\section{Discussion}

Low-shore assemblages on artificial structures, either on landward or seaward sides of breakwaters, were characterized by a low number of taxa, in accordance with patterns documented on breakwaters along other sedimentary coasts in the Mediterranean and in the North-east Atlantic (Bacchiocchi and Airoldi, 2003; Moschella et al., 2005; Pinn et al., 2005; Gacia et al., 2007). These patterns are not surprising given that artificial structures, being generally located in urban or industrial areas, are commonly subjected to poor environmental conditions (e.g. release of pollutants and nutrients, high rates of sedimentation), which are known to affect negatively

215 macroalgal diversity (Krause-Jensen et al., 2007).

At low-shore levels, the artificial habitats we investigated supported a smaller number of taxa $($ mean $\pm \mathrm{SE}=4.45 \pm 0.09 ; n=240)$ than nearby rocky shores, located about $15 \mathrm{~km}$ south $(11.16 \pm$ 0.18; $n=192$; Benedetti-Cecchi et al., unpublished data). Assemblages on artificial structures represented a subset of the regional pool of hard-bottom species, as all the species they supported were common on local rocky shores. This would indicate that a relatively large number of species is not able to establish viable populations on these surfaces. Severe sand scouring during swells may 
VASELLI et al.

reduce the number of species able to recruit and/or survive on these structures. Alternatively, lack of supply of larvae, spores or propagules for colonization could explain the low species diversity.

225 This is, however, unlikely to occur, given the relatively short distance between this site and natural rocky shores or reefs. Our results, in accordance with those of other studies (Bacchiocchi and Airoldi, 2003; Moschella et al., 2005; Pinn et al., 2005; Gacia et al., 2007) would suggest that these artificial habitats do not represent surrogate habitats for many rocky-bottom species, allowing few "opportunistic" organisms to achieve dominance.

Variation between the landward and the seaward side of breakwaters was mainly caused by four taxa, with encrusting corallines, Corallina elongata and Mytilus galloprovincialis more abundant on the seaward side of breakwaters and filamentous algae on the landward side. Other studies have reported similar patterns of distribution of organisms around breakwaters (Bacchiocchi and Airoldi, 2003; Bulleri and Airoldi, 2005; Moschella et al., 2005; Gacia et al., 2007). Mussels and barnacles have been repeatedly found to be more abundant on wave-exposed sides of artificial structures (Bacchiocchi and Airoldi, 2003; Moschella et al., 2005; Gacia et al., 2007). At our study sites, the landward side of breakwaters was completely free from mussels. This could be the result of poor circulation of water reducing the supply of food or enhancing the deposition of fine sediments on the surface of blocks. In accordance with Gacia et al. (2007), much of the free space on the landward side of breakwaters was indeed covered by a thick layer of sediment (F. Bulleri, personal observation). High sedimentation rates can cause smothering of filter-feeders like barnacles and mussels, favouring the dominance by filamentous or turf-forming algae (Airoldi, 2003). Interestingly, throughout the duration of the study there was a trend for M. galloprovincialis

245 to progressively monopolize space at the expense of $C$. elongata. This could indicate an ongoing process of recovery of space by mussel beds after a particularly severe storm disrupted their integrity or, alternatively, could reflect a successful event of recruitment. In contrast to patterns 
VASELLI et al.

documented by Airoldi et al. (2005b) in the northern Adriatic Sea, recreational harvesting of mussels is not a common practice at our study site.

The main space-occupiers on the seaward side of breakwaters, M. galloprovincialis and $C$. elongata, are commonly found on nearby wave-exposed natural rocky shores (Livorno, about 15 km south), but never at such high values of percentage cover (Menconi et al., 1999; BenedettiCecchi, 2001). Either physical features of artificial habitats (e.g. size and topography of the blocks and their spatial arrangement) or water quality could have contributed to determine their dominance at our study site. The proximity of breakwaters to the mouth of the Arno River might have created highly suitable conditions for the recruitment and growth of mussels (i.e. supply of suspended organic matter). Great similarity between assemblages in wave-exposed habitats on these breakwaters and those on a rocky shore influenced by the Magra River, about $50 \mathrm{~km}$ north, (i.e. dominance of mussels; Benedetti-Cecchi et al., 2000) would suggest a strong influence of inputs of freshwater at our study site. The relatively large cover of Corallina elongata, a stenohaline species (Doty and Newhouse 1954), suggests however that factors other than the proximity to a river contribute to regulate the structure of low-shore assemblages on these structures.

Filamentous algae were present on the seaward side of breakwaters, but exclusively as epiphytes of mussels and Corallina elongata and with temporally variable percentage cover, greater in summer/autumn and close to zero in winter. In contrast, filamentous algae dominated wavesheltered habitats consistently through time. Here, it is worth stressing that, while mosaics of patches occupied by mussels or C. elongata have been documented in the region (Benedetti-Cecchi et al., 2000), persistent domination of space by filamentous forms has not been previously reported on open coasts. The provision of sheltered habitats may therefore generate physical conditions leading to the monopolization of space at low-shore levels by opportunistic forms and, ultimately, to the persistence of assemblages very different from those observed on natural rocky substrata in 
VASELLI et al.

the region. If assemblages on the seaward side of breakwaters resemble, to some extent, those found on rocky shores in the region that are subjected to a similar influence of freshwater inputs, those on the landward side are to be considered habitats of their own, with artificial patterns and processes (Bulleri, 2005).

Assemblages on landward and seaward sides of breakwaters also differed in terms of temporal stability. Mechanical disturbance by waves is likely to vary greatly in intensity and frequency between exposed and sheltered habitats. Availability of bare space was greater on the landward than on the seaward side of breakwaters, consistently through time, suggesting that factors other than the wave-generated removal of biomass produced the observed patterns. Great availability of empty space has been previously documented on rip-rap seawalls built in wave-sheltered areas of San Diego Bay, in southern California (Davis et al., 2002). Due to poor water exchange, conditions on the landward side of breakwaters could be sufficiently harsh (e.g. high rates of deposition of sediments) to allow the persistence of few species, with little temporal variation in their covers. Indeed one single functional group, the filamentous algae, and, to a lesser extent, one exotic species, C. racemosa, were able to hold space consistently through time. Both of these are highly tolerant to sedimentation (Airoldi, 2003; Piazzi et al., 2007). Filamentous forms generally formed dense mats, making identification to species or genus unfeasible in the field. The same species were, however, found at different times of the year, suggesting low species turnover within this functional group (authors' personal observation). Variation between assemblages on the landward and the seaward side of breakwaters did not, in contrast, differ at the scale of 10 s of $\mathrm{m}$ (i.e. between areas). This would indicate that although the factors influencing the distribution of organisms in these contrasting habitats are likely to differ (i.e. wave-action and sedimentation, in exposed and sheltered habitats, respectively), they operated consistently within breakwaters. 
VASELLI et al.

Dominance by filamentous algae, associated with large availability of unoccupied space, on the landward side of breakwaters, may acquire great importance when considering the ecology of invasive species. In this study, we found a high cover of the introduced macroalga Caulerpa racemosa on the landward side of breakwaters. Although this alga is able to colonize a variety of natural substrata (Piazzi et al. 2005), here, it was not found on sandy bottoms sheltered by breakwaters. C. racemosa can tolerate high rates of sedimentation (Piazzi et al., 2007) and its colonization and spread are facilitated by the presence of algal turfs (Ceccherelli et al., 2002;

Bulleri and Benedetti-Cecchi, in press). Hence, domination by algal turfs in wave-sheltered habitats could have favoured the establishment of this invader. Importantly, this species is commonly found on exposed coasts and its distribution does not seem to be regulated by wave-exposure (Bulleri and Benedetti-Cecchi, in press). Hence, lack of this species on the seaward side of breakwaters may suggest that organisms that occupied space on these surfaces were somehow effective in preventing its establishment. Recent experimental work has shown that the spread and growth of C. racemosa is enhanced on complex surfaces (Bulleri and Benedetti-Cecchi, in press); according to these findings, mussel beds would represent suitable surfaces for C. racemosa, favouring the attachment of its prostrate stolons. Mussels and organisms intimately associated with them, such as epiphytes or those interstitially, are susceptible to dislodgement by waves. This mechanism is, however, unlikely to explain the complete absence of $C$. racemosa in wave-exposed artificial habitats.

Greater stability of assemblages on the landward side of breakwater could foster the persistence of C. racemosa. In the Mediterranean Sea, this alga shows strong seasonal fluctuations and, on the closest shallow natural rocky substrata (3-6 $\mathrm{m}$ in depth), it virtually disappears from November to March, to grow back in early spring and peak in abundance in September-October (Bulleri and Benedetti-Cecchi in press). Here, C. racemosa showed a similar trend, but its cover was still very high in early winter, a time of the year at which it has generally undergone a considerable decrease (Bulleri and Benedetti-Cecchi in press). Thus, wave-sheltered artificial 
VASELLI et al.

habitats may not only provide suitable hard substrata for this species within an otherwise sandy area, but would also enhance its persistence through time. This may, in turn, enable this species to generate more biomass and produce more and bigger fragments, enhancing its long distance dispersal.

Although its cover did not reach values worth of formal analysis, a second non-indigenous species, the green alga Codium fragile spp. tomentosoides, was recorded on the landward side of breakwaters in December 2007. The results of this study, documenting the lack of $C$. fragile ssp. tomentosoides on the seaward side of breakwaters, confirm that wave-sheltered artificial habitats represent ideal habitats for this species (Bulleri and Airoldi, 2005; Bulleri et al., 2007). Since, in contrast to C. racemosa, the recruitment of parthenogenetic zygotes $C$. fragile ssp. tomentosoides is enhanced on primary substrata (Bulleri and Airoldi, 2005), the large availability of unoccupied space on the landward side of the breakwaters at Marina di Pisa let us predict a further increase in the local abundance of this species.

In summary, the results of this study suggest that the deployment of hard coastal-defence structures, attracting a suite of rocky-bottom species, has the potential to alter patterns of abundance and distributions of species at local and regional scale (Bulleri, 2005). These structures can function as "stepping stones" (sensu Glasby and Connell, 1999), enabling species to disperse across areas lacking of suitable habitat, disrupting natural patterns of dispersion and influencing gene flow, with 345 potential evolutionary consequences. In particular, the provision of wave-sheltered surfaces determines the occurrence of assemblages different from those that can be found on comparable natural hard substrata. These are characterized by low functional diversity (one morphological group of algae), large availability of free space and great temporal stability. These features can have positive implications for the establishment and spread of exotic species (Davis et al., 2000; Stachowicz et al., 2002). This study, documenting the presence of two of the most widespread 
VASELLI et al.

invasive seaweeds (Williams and Smith, 2007), strengthen the results of previous works that have identified man-made structures as important corridors for the expansion of introduced species (Glasby and Connell, 1999; Bulleri and Airoldi, 2005).

In this light, further research on the ecological impacts and ecological role of these structures, whose presence is predicted to increase due to climatic and socio-economic reasons, is urgently needed to plan strategies for the conservation of marine biodiversity and for the management of biological invasions. Our study suggests that the provision of sheltered habitats should be of particular concern when planning the deployment of hard coastal-defence structures. Alternative options in the design of these structures may minimize their impacts. For instance, deploying structures that allow higher circulation of water around landward surfaces would serve to improve physical conditions, enabling the development of assemblages more similar to those occurring on natural rocky coasts. Achieving these goals requires, however, the integration of ecological criteria into the decision-making process which is, at present, mostly based on social and economic 365 objectives.

\section{Acknowledgements}

We sincerely thank I. Bertocci, E. Maggi and L. Tamburello for their help in the field. This study was partially supported by the Comune di Pisa and it is publication number MPS-xx of MARBEF

370 Network of Excellence. Procedures used in the present study comply with Italian laws.

\section{References}

Airoldi, L., 2003. The effects of sedimentation on rocky coast assemblages. Oceanography and Marine Biology: An Annual Review 41, 161-263. 
VASELLI et al.

Airoldi, L., Abbiati, M., Beck, M.W., Hawkins, S.J., Jonsson, P.R., Martin, D., Moschella, P.S., Sundelöf, A., Thompson, R.C., Åberg, P., 2005a. An ecological perspective on the deployment and design of low-crested and other hard coastal defence structures. Coastal Engineering 52, 1073-1087.

Airoldi, L., Bacchiocchi, F., Cagliola, C., Bulleri, F., Abbiati, M., 2005b. Impact of recreational harvesting on assemblages in artificial rocky habitats. Marine Ecology Progress Series 299, 55-66.

Airoldi, L., Beck, M.W., 2007. Loss, status, and trends for coastal marine habitats of Europe. Oceanography and Marine Biology: An Annual Review 45, 345-405.

385 Anderson, M.J., 2001. A new method for non-parametric multivariate analysis of variance. Austral Ecology 26, 32-46.

Bacchiocchi, F., Airoldi, L., 2003. Distribution and dynamics of epibiota on hard structures for coastal protection. Estuarine Coastal and Shelf Science 56, 1157-1166.

Barros, F., Underwood, A.J., Lindegarth, M., 2001. The influence of rocky reefs on the structure of benthic macrofauna in nearby soft-sediments. Estuarine Coastal and Shelf Science 52, $191-199$.

Benedetti-Cecchi, L., 2001. Variability in abundance of algae and invertebrates at different spatial scales on rocky sea shores. Marine Ecology Progress Series 215, 79-92.

Benedetti-Cecchi, L., Bulleri, F., Cinelli, F. 2000. The interplay of physical and biological factors in maintaining mid-shore and low-shore assemblages on rocky coasts in the northwest Mediterranean. Oecologia 123, 406-417.

Bray, M.J., Hooke, J.M., 1997. Prediction of soft-cliff retreat with accelerating sea level rise. Journal of Coastal Research 13, 453-467.

Bulleri, F., 2005. The introduction of artificial structures on marine soft- and hard-bottoms: ecological implications of epibiota. Environmental Conservation 32, 101-102. 
VASELLI et al.

Bulleri, F., 2006. Is it time for urban ecology to include the marine realm? Trends in ecology and Evolution, 21, 658-659.

Bulleri, F., Airoldi, L., 2005. Artificial marine structures facilitate the spread of a nonindigenous green alga, Codium fragile ssp tomentosoides, in the North Adriatic Sea. Journal of Applied Ecology 42, 1063-1072.

Bulleri, F., Benedetti-Cecchi, L., in press. Facilitation of the introduced green alga, Caulerpa racemosa, by resident algal turfs: experimental evaluation of underlying mechanisms. Marine Ecology Progress Series.

Bulleri, F., Branca, G.M., Abbiati, M., Airoldi, L. 2007. Development of reproductive structures in the introduced green alga, Codium fragile ssp. tomentosoides, in the northern Adriatic Sea. European Journal of Phycology 42, 137-144.

Carr, M.H., Hixon, M.A., 1997. Artificial reefs: the importance of comparisons with natural reefs. Fisheries 22, 28-33.

Ceccherelli, G., Piazzi, L., Balata, D., 2002. Spread of introduced Caulerpa species in macroalgal habitats. Journal of Experimental Marine Biology and Ecology 280, 1-11.

Chapman, M.G., 2003. Paucity of mobile species on constructed seawalls: effects of urbanization on biodiversity. Marine Ecology Progress Series 264, 21-9.

Chapman, M.G., 2006. Intertidal seawalls as habitats for molluscs. Journal of Molluscan Studies $72,247-257$.

Chapman, M.G., Bulleri, F., 2003. Intertidal seawalls-new features of landscape in intertidal environments. Landscape and Urban Planning 62, 19-172.

Clarke, K.R., 1993. Non-parametric multivariate analyses of changes in community structure. Austral Journal of Ecology 18, 117-143

Clynick, B.G., 2006. Assemblages of fish associated with coastal marinas in north-western Italy. Journal of the Marine Biological Association of the United Kingdom 86, 847-852. 
VASELLI et al.

Collins, K.J., Jensen, A.C., Lockwood, A.P.M., Lockwood, S.J., 1994. Coastal structures, waste materials and fishery enhancement. Bulletin of Marine Science 55, 1240-1250.

Connell, S.D., 2001. Urban structures as marine habitats: an experimental comparison of the composition and abundance of subtidal epibiota among pilings, pontoons and rocky reefs. Marine Environmental Research 52, 115- 125.

Connell, S.D., Glasby, T.M., 1998. Do urban structures influence local abundances and diversity of subtidal epibiota? A case study from Sydney Harbour, Australia. Marine Environmental Research 47, 373-387.

Davis, N., Vanblaricom, G.M., Dayton, P.K., 1982. Man-made structures on marine sediments: effects on adjacent benthic communities. Marine Biology 70, 295-303.

Davis, M.A, Grime, J. P., Thompson, K., 2000. Fluctuating resources in plant communities; a general theory of invasibility. Journal of Ecology 88, 528-534.

Davis, J.L.D., Levin, L.A., Walther, S.M., 2002. Artificial armored shorelines: sites for opencoast species in a southern California Bay. Marine Biology 140, 1249-1262.

Denny, M. 1995. Predicting physical disturbance: mechanistic approaches to the study of survivorship on wave-swept shores. Ecological Monographs 65, 371-418.

Dethier, M.N., Graham, E.S., Cohen, S., Tear, L.M., 1993. Visual versus random-point percent cover estimations: 'Objective' is not always better. Marine Ecology Progress Series 110, $9-18$.

445 Doty, M.S., Newhouse, J., 1954. The distribution of marine algae into estuarine waters. American Journal of Botany 41, 508-515.

EEA, 1999. Coastal and marine zones. Chapter 3.14. Environment in the European Union at the Turn of the Century. State of Environment report No 1/1999. Copenahagen: EEA. Online. Available HTTP: http://reports.eea.eu.int/92-9157-202-0/en. 
VASELLI et al.

Gacia, E., Satta, M.P., Martin, D., 2007. Low crested coastal defence structures on the Catalan coast of the Mediterranean Sea: how they compare with natural rocky shores. Scientia Marina 71, 259-267.

Glasby, T.M., 1999. Differences between subtidal epibiota on pier pilings and rocky reefs at marinas in Sydney, Australia. Estuarine Coastal and Shelf Science 48, 281-290.

Glasby, T.M., Connell, S.D., 1999. Urban structures as marine habitats. Ambio 28, 595-598.

Glasby, T.M., Connell, S.D., Holloway, M.G., Hewitt C.L., 2006. Nonindigenous biota on artificial structures: could habitat creation facilitate biological invasions? Marine Biology $151,887-895$.

Guidetti, P., 2004. Fish assemblages associated with coastal defence structures in south-western Italy (Mediterranean Sea). Journal of the Marine Biological Association of the United Kingdom 84, 669-670.

Krause-Jensen, D., Carstensen, J., Karsten, D., 2007. Total and opportunistic algal cover in relation to environmental variables. Marine Pollution Bullettin 55, 114-125.

Martin, D., Bertasi, F., Colangelo, M.A., de Vries, M., Frost, M., Hawkins, S.J., Macpherson, E., Moschella, P.S., Satta, M.P., Thompson, R.C., Ceccherelli, V.U., 2005. Ecological impact of coastal defence structures on sediments and mobile infauna: evaluating and forecasting consequences of unavoidable modifications of native habitats. Coastal Engineering 52, 1027-1051.

Menconi, M., Benedetti-Cecchi, L., Cinelli, F., 1999. Spatial and temporal variability in the 470 distribution of algae and invertebrates on rocky shores in the northwest Mediterranean. Journal of Experimental Marine Biology and Ecology 233, 1-23.

Moreira, J., Chapman, M.G., Underwood, A.J. 2007. Maintenance of chitons on seawalls using crevices on sandstone blocks as habitat in Sydney Harbour, Australia. Journal of Experimental Marine Biology and Ecology 347, 134-143. 
VASELLI et al.

Moschella, P.S., Abbiati, M., Åberg, P., Airoldi, L., Anderson, J.M., Bacchiocchi, F., Bulleri, F., Dinesen, G.E., Frost, M., Gacia, E., Granhag, L., Jonsson, P.R., Satta, M.P., Sundelof, A., Thompson, R.C., Hawkins, S.J., 2005. Low-crested coastal defence structures as artificial habitats for marine life: using ecological criteria in design. Coastal Engineering 52, 1053-1071.

Piazzi, L., Meinesz, A., Verlaque, M., Akçali, B., Antolic’', B., Argyrou, M., Balata, D., Ballesteros, E., Calvo, S., Cinelli, F., Cirik, S., Cossu, A., D’Archino, R., Djellouli, S.A., Javel, F., Lanfranco, E., Mifsud, C., Pala, D., Panayotidis, P., Peirano, A., Pergent, G., Petrocelli, A., Ruitton, S., Žuljevic', A., Ceccherelli, G., 2005. Invasion of Caulerpa racemosa var. cylindracea (Caulerpales, Chlorophyta) in the Mediterranean Sea: an assessment of the early stages of spread. Cryptogamie Algologie 26, 189-202.

Piazzi, L., Balata, D., Foresi, L., Cristaudo, C., Cinelli, F., 2007. Sediment as a constituent of Mediterranean benthic communities dominated by Caulerpa racemosa var. cylindracea. Scientia Marina 71, 129-135.

Pinn, E.H., Mitchell, K., Corkill, J., 2005. The assemblages on groynes in relation to substratum age, aspect and microhabitat. Estuarine Coastal and Shelf Science, 62, 271-282.

Searle, S.R., Casella, G., McCulloch C.E., 1992. Variance components. John Wiley \&Sons, Inc., New York.

Stachowicz, J.J., Fried, H., Osman, R.W., Whitlatch, R.B., 2002. Biodiversity, invasion resistance, and marine ecosystem function: reconciling pattern and process. Ecology, 83, 2575-2590.

Steneck, R.S., Dethier, M.N., 1994. A functional group approach to the structure of algaldominated communities. Oikos 69, 476-498.

Terlizzi, A., Anderson, M.J., Fraschetti, S., Benedetti-Cecchi, L., 2007. Scales of spatial variation in Mediterranean subtidal sessile assemblages at different depths. Marine Ecology Progress Series 332, 25-39. 


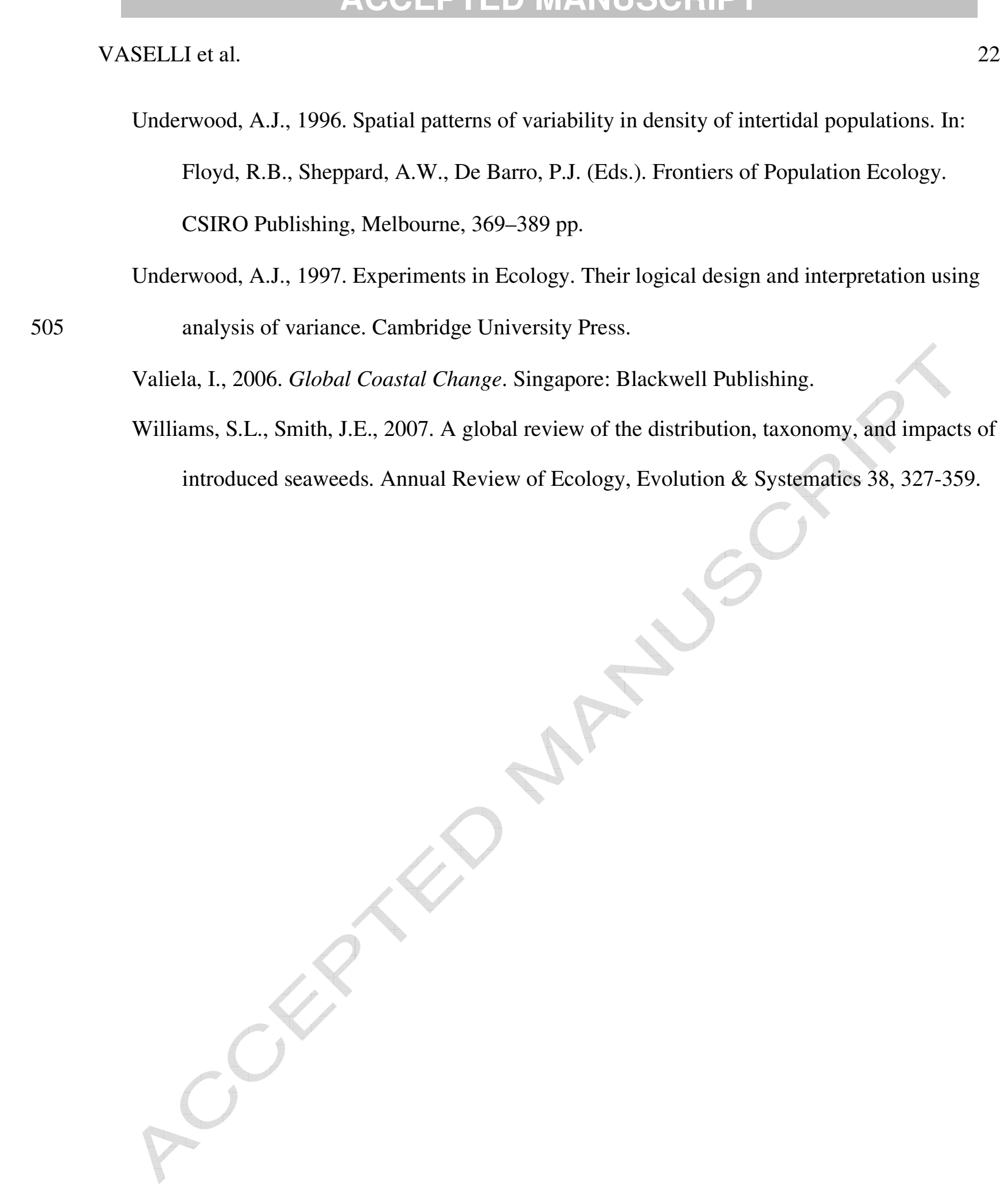


VASELLI et al.

Legend fo Figures

Fig. 1. Map of the study area, showing the strecth of shores where breakwaters have been deployed.

Fig. 2. nMDS plot comparing assemblages on different side of breakwaters during October 2006.

Different symbols (quadrats and circles) represent the two breakwaters; each of these is a centroid of each area within each breakwater.

Fig. 3. Abundance of common taxa and bare rock at each date of sampling. Bars are the average value for each breakwater (mean + SE, $n=15$ in October 2006 and $n=10$ in December 2006, May 2007 and October 2007, data averaged across Replicates and Areas). The dotted line represents the start of the implemented design.

Fig. 4. nMDS plots comparing assemblages on different sides of breakwaters in December 2006 (circles), May 2007 (quadrats) and October 2007 (triangles). Each symbol is a centroid of an area.

Fig. 5. Number of taxa at each date of sampling. Bars are the average value for each breakwater (mean + SE, $n=15$ in October 2006 and $n=10$ in December 2006, May 2007 and October 2007, data averaged across Replicates and Areas). The dotted line represents the start of the implemented design.

Fig. 6. Multivariate temporal (A) and spatial (B) variance illustrating differences between exposures. Bars are the average values $(+\mathrm{SE})$ across breakwaters $(n=4)$ (see text for further details). 
VASELLI et al.

Table 1. PERMANOVA testing for the effects of wave-exposure and breakwaters on the structure of low-shore assemblages in October 2006.

\begin{tabular}{|c|c|c|c|c|c|c|}
\hline $\begin{array}{l}\text { Source of } \\
\text { variation }\end{array}$ & & d.f. & MS & pseudo $F$ & $P$ & $\begin{array}{l}\text { Permutable units and } \\
\text { denominator for } F\end{array}$ \\
\hline Exposure & $=\mathrm{E}$ & 1 & 91242.0 & 44.10 & 0.008 & 4 E x B cells \\
\hline Breakwater & $=\mathrm{B}$ & 1 & 4010.9 & 1.44 & 0.235 & 12 Replicate Areas \\
\hline $\mathrm{E} \times \mathrm{B}$ & & 1 & 2068.8 & 0.74 & 0.549 & 12 Replicate Areas \\
\hline Area (E x B) & & 8 & 2771.1 & 4.13 & 0.001 & 60 Replicate Obs \\
\hline Residual & & 48 & 670.1 & & & \\
\hline
\end{tabular}


Tab. 2., continued

\begin{tabular}{|c|c|c|c|c|c|}
\hline \multirow[b]{2}{*}{ Source of Variability } & \multicolumn{3}{|c|}{ Bare rock } & \multicolumn{2}{|c|}{$\begin{array}{c}\text { Number of } \\
\text { Taxa }\end{array}$} \\
\hline & d.f. & $\mathrm{MS}$ & $F$ & MS & $F$ \\
\hline Exposure $=\mathrm{E}$ & 1 & $26.99^{\mathrm{a}}$ & $8.70 *$ & 0.01 & 0.00 \\
\hline Breakwater $=\mathrm{B}$ & 1 & 4.83 & 1.56 & 0.15 & 0.04 \\
\hline $\mathrm{E} \times \mathrm{B}$ & 1 & 1.30 & Eliminated & 8.81 & 2.18 \\
\hline $\operatorname{Area}(\mathrm{E} \times \mathrm{B})$ & 8 & 3.10 & $2.87 *$ & 4.05 & $2.33 *$ \\
\hline Residual & 48 & 1.08 & & 1.74 & \\
\hline Cochran's Test & & \multicolumn{2}{|c|}{$\mathrm{C}=0.19$} & \multicolumn{2}{|c|}{$\mathrm{C}=0.15$} \\
\hline Transformation & & \multicolumn{2}{|c|}{$\operatorname{Ln}(x+1)$} & \multicolumn{2}{|c|}{ None } \\
\hline
\end{tabular}

${ }^{\mathrm{a}}$ Tested on Area(E x B) 
Table 3. PERMANOVA testing for the effects of date of sampling, breakwater and wave-exposure on the structure of low-shore assemblages. Whenever the analysis showed a

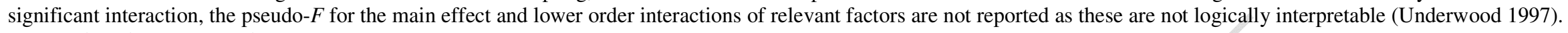
$\mathrm{L}=$ Landward; $\mathrm{S}=$ Seaward.

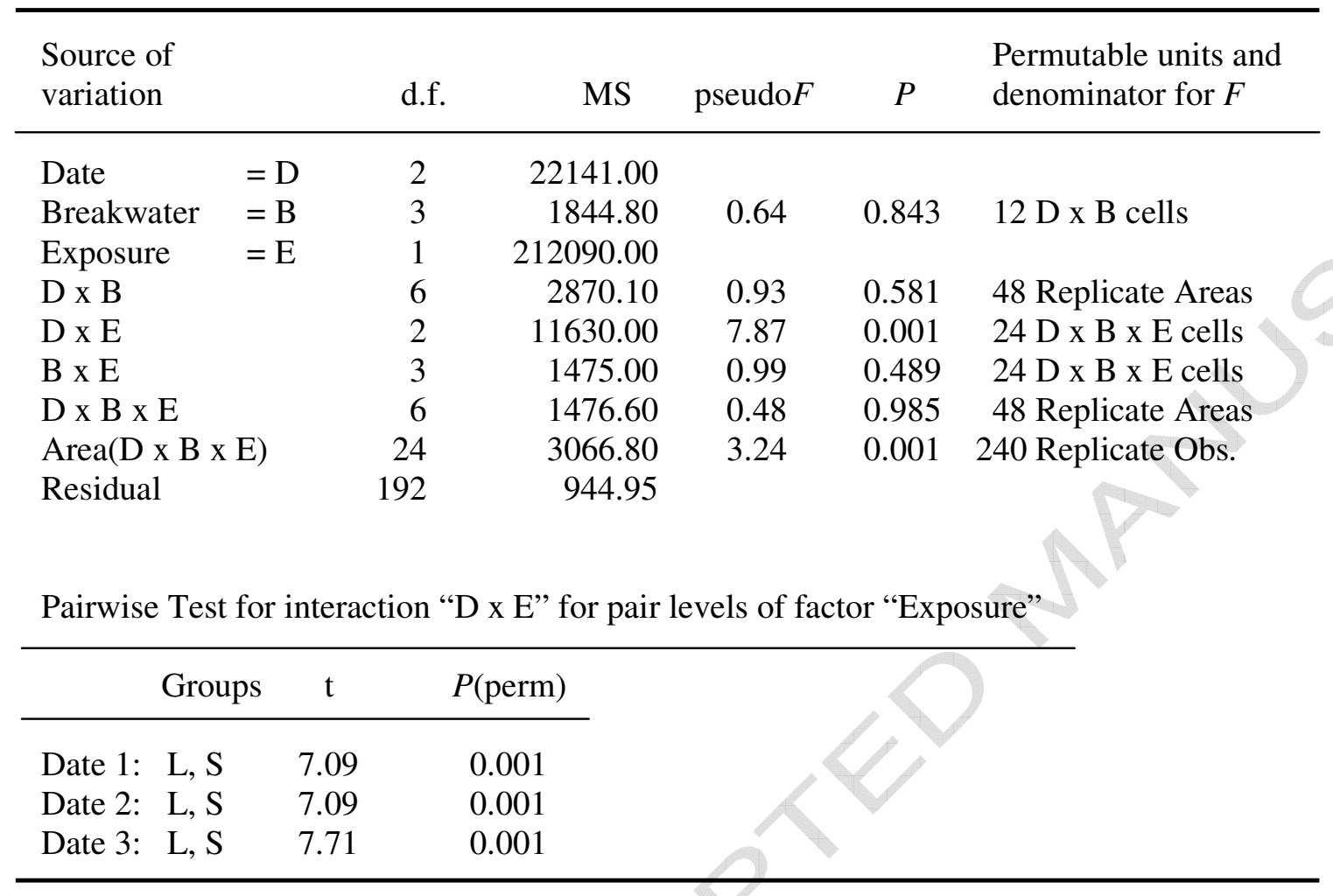


Table 4. ANOVAs testing for the effects of date of sampling, breakwater and wave-exposure on the abundance of common taxa. $*, P<0.05 ; * *, P<0.01 ; * * *, P<0.001$.

Whenever the analysis showed a significant interaction, the $F$-ratio for the main effect and lower order interactions of relevant factors are not reported as these are not logically interpretable (Underwood 1997). When necessary, pooling procedures were applied according to Underwood (1997). L = Landward; S = Seaward

\begin{tabular}{|c|c|c|c|c|c|c|c|c|c|c|}
\hline \multirow[b]{2}{*}{ Source of Variability } & \multirow[b]{2}{*}{ d.f. } & \multicolumn{2}{|c|}{$\begin{array}{l}\text { Caulerpa } \\
\text { racemosa }\end{array}$} & \multicolumn{2}{|c|}{$\begin{array}{l}\text { Filamentous } \\
\text { algae }\end{array}$} & \multicolumn{2}{|c|}{$\begin{array}{r}\text { Corallina } \\
\text { elongata }\end{array}$} & $\begin{array}{l}\text { Encrusting } \\
\text { corallines }\end{array}$ & \multicolumn{2}{|c|}{$\begin{array}{c}\text { Mytilus } \\
\text { galloprovincialis }\end{array}$} \\
\hline & & MS & $F$ & MS & $F$ & MS & $F$ & MS & MS & $F$ \\
\hline Date $=\mathrm{D}$ & 2 & 2003.85 & & 17813.78 & & 6973.13 & & $7.5310 .99 * *$ & 4421.02 & \\
\hline Breakwater $=\mathrm{B}$ & 3 & 138.29 & 0.90 & 785.98 & 0.38 & 579.49 & 1.81 & 0.91 & 278.90 & 1.15 \\
\hline Exposure $=\mathrm{E}$ & 1 & 2287.83 & & 39835.27 & & 77868.04 & & $37.95^{\mathrm{a}} 20.34^{*}$ & 97364.82 & \\
\hline $\mathrm{D} \times \mathrm{E}$ & 2 & 2003.85 & $13.02 * *$ & 5453.55 & $6.85 *$ & 3371.78 & $30.27 * * *$ & $\begin{array}{ll}1.86 & 3.01\end{array}$ & 4421.09 & $18.25 * *$ \\
\hline $\mathrm{B} \times \mathrm{E}$ & 3 & 138.29 & 0.90 & 567.01 & 0.71 & 140.79 & 1.26 & 0.36 Eliminated & 278.90 & 1.15 \\
\hline $\mathrm{D} \times \mathrm{B} \times \mathrm{E}$ & 6 & 153.90 & 0.37 & 796.18 & 0.69 & 111.39 & 0.25 & 0.610 .43 & 242.23 & 0.15 \\
\hline Residual & 192 & 56.32 & & 409.81 & & 253.56 & & 0.59 & 270.78 & \\
\hline Cochran's Test & & $\mathrm{C}=0.48^{*}$ & & $\mathrm{C}=0.07$ & & $\mathrm{C}=0.09$ & & $\mathrm{C}=0.07$ & $\mathrm{C}=0.10$ & \\
\hline \multicolumn{2}{|l|}{ SNK Test for "D $x$ E" } & \multicolumn{2}{|c|}{ Date 3: $L>S$} & \multicolumn{2}{|c|}{ Date 3: L>S } & \multicolumn{2}{|c|}{ Date 1: $L<S$} & & \multicolumn{2}{|c|}{ Date 1: $\mathrm{L}<\mathrm{S}$} \\
\hline S.E.: & & 1.9615 & & 4.4615 & & 1.6688 & & & 2.4609 & \\
\hline
\end{tabular}

${ }^{\mathrm{a}}$ Tested on D x E 
Table 4., continued

\begin{tabular}{|c|c|c|c|c|c|}
\hline \multirow[b]{2}{*}{ Source of Variability } & \multicolumn{3}{|c|}{ Bare Rock } & \multicolumn{2}{|c|}{ Number of taxa } \\
\hline & d.f. & MS & $F$ & MS & $F$ \\
\hline Date $\quad=\mathrm{D}$ & 2 & 25.73 & $9.47 *$ & 1.13 & 0.79 \\
\hline Breakwater $=\mathrm{B}$ & 3 & 6.00 & 2.21 & 1.47 & 1.02 \\
\hline Exposure $=\mathrm{E}$ & 1 & $77.24^{\mathrm{a}}$ & $46.21 *$ & $0.00^{\mathrm{a}}$ & a $\quad 0.00$ \\
\hline $\operatorname{Area}(D \times B \times E)$ & 24 & 2.81 & $1.79 *$ & 4.38 & $2.44 * * *$ \\
\hline $\mathrm{D} \times \mathrm{B}$ & 6 & 2.71 & 0.97 & 1.44 & 0.33 \\
\hline $\mathrm{D} \times \mathrm{E}$ & 2 & 1.67 & 0.61 & 6.41 & 2.54 \\
\hline $\mathrm{B} \times \mathrm{E}$ & 3 & 1.71 & Eliminated & 2.54 & Eliminated \\
\hline $\mathrm{D} \times \mathrm{B} \times \mathrm{E}$ & 6 & 2.73 & 0.97 & 2.52 & 0.58 \\
\hline Residual & 192 & 1.56 & & 1.72 & \\
\hline Cochran's Test & & $\mathrm{C}=0.05$ & & $\mathrm{C}=0.07$ & \\
\hline Transformation & & $\operatorname{Ln}(x+1)$ & & None & \\
\hline
\end{tabular}

${ }^{\mathrm{a}}$ Tested on D x E 
VASELLI et al.

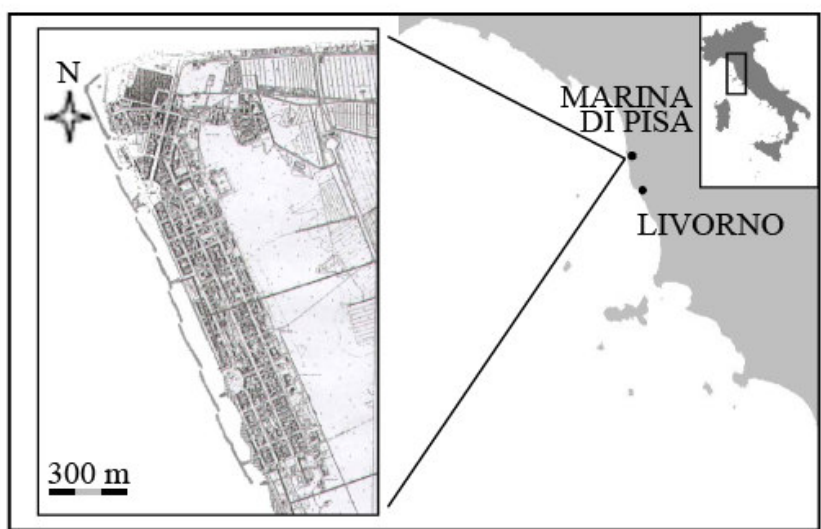

Fig. 1 Vaselli et al. 
VASELLI et al.

$\square$ Landward

- Seaward

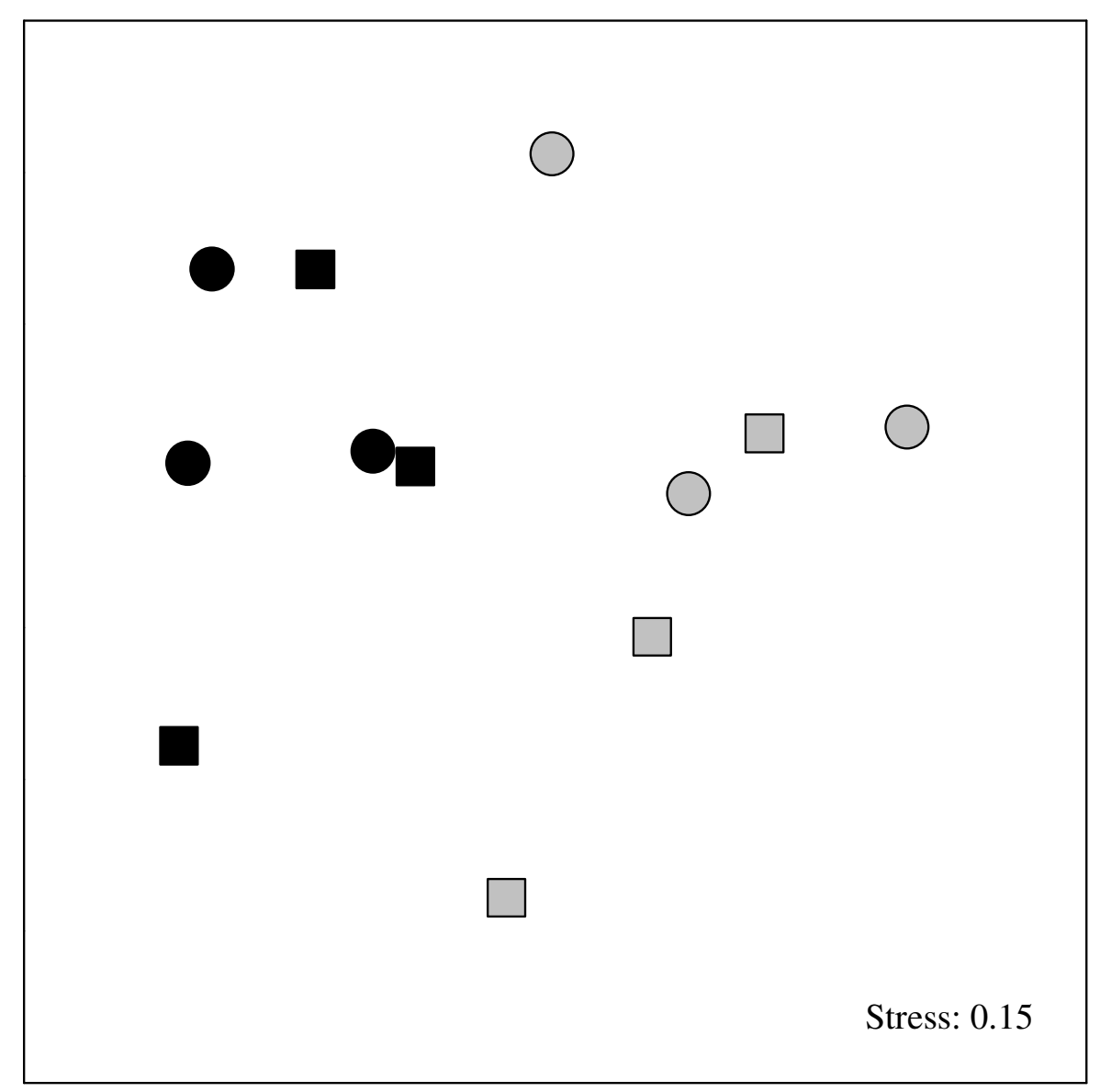

Fig. 2 Vaselli et al. 
Landward

Seaward

A Mytilus galloprovincialis

B Corallina elongata
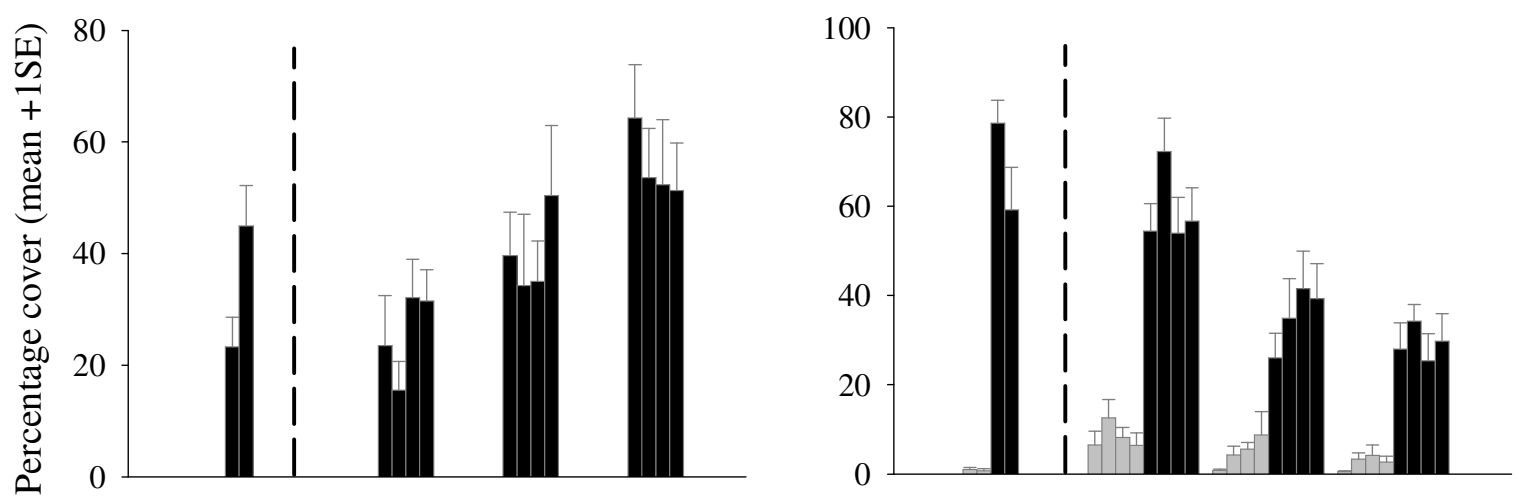

C Filamentous algae

D Caulerpa racemosa
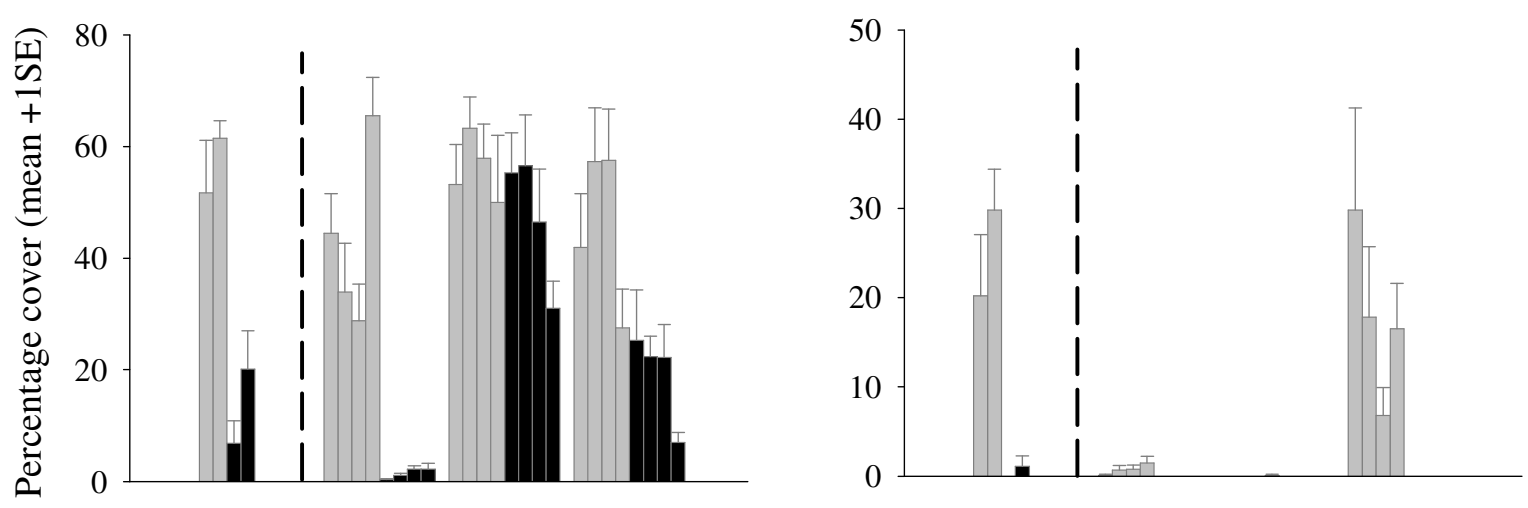

E Bare rock

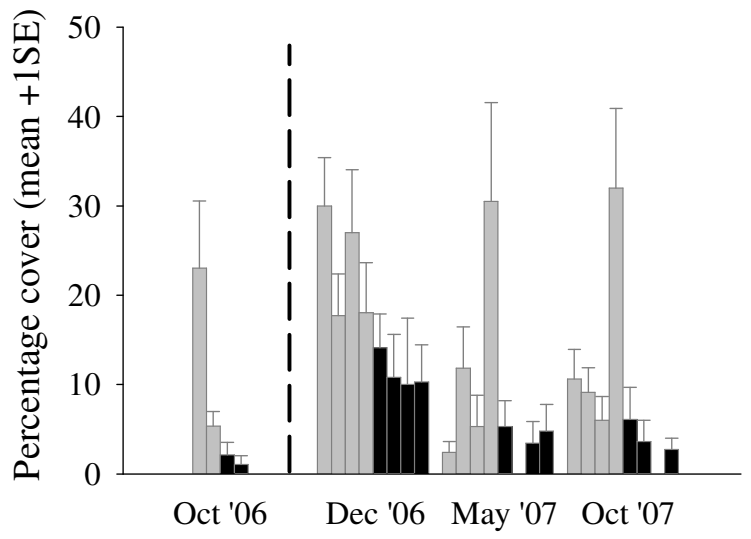

F Encrusting corallines

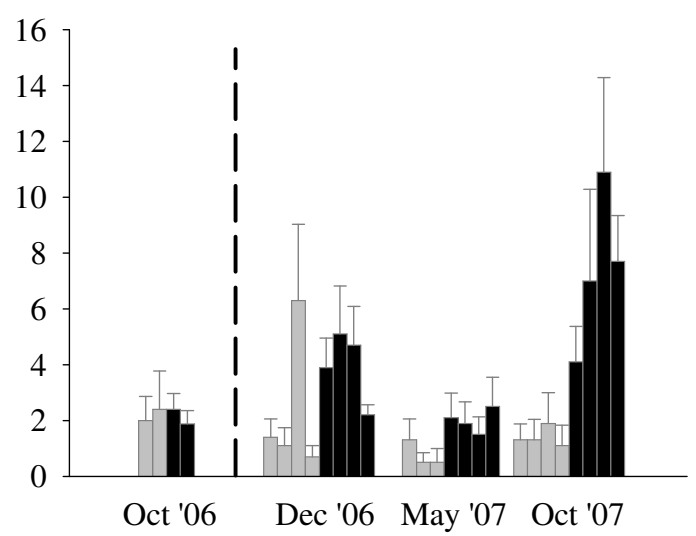

Fig. 3 Vaselli et al. 
VASELLI et al.

Landward

- Seaward

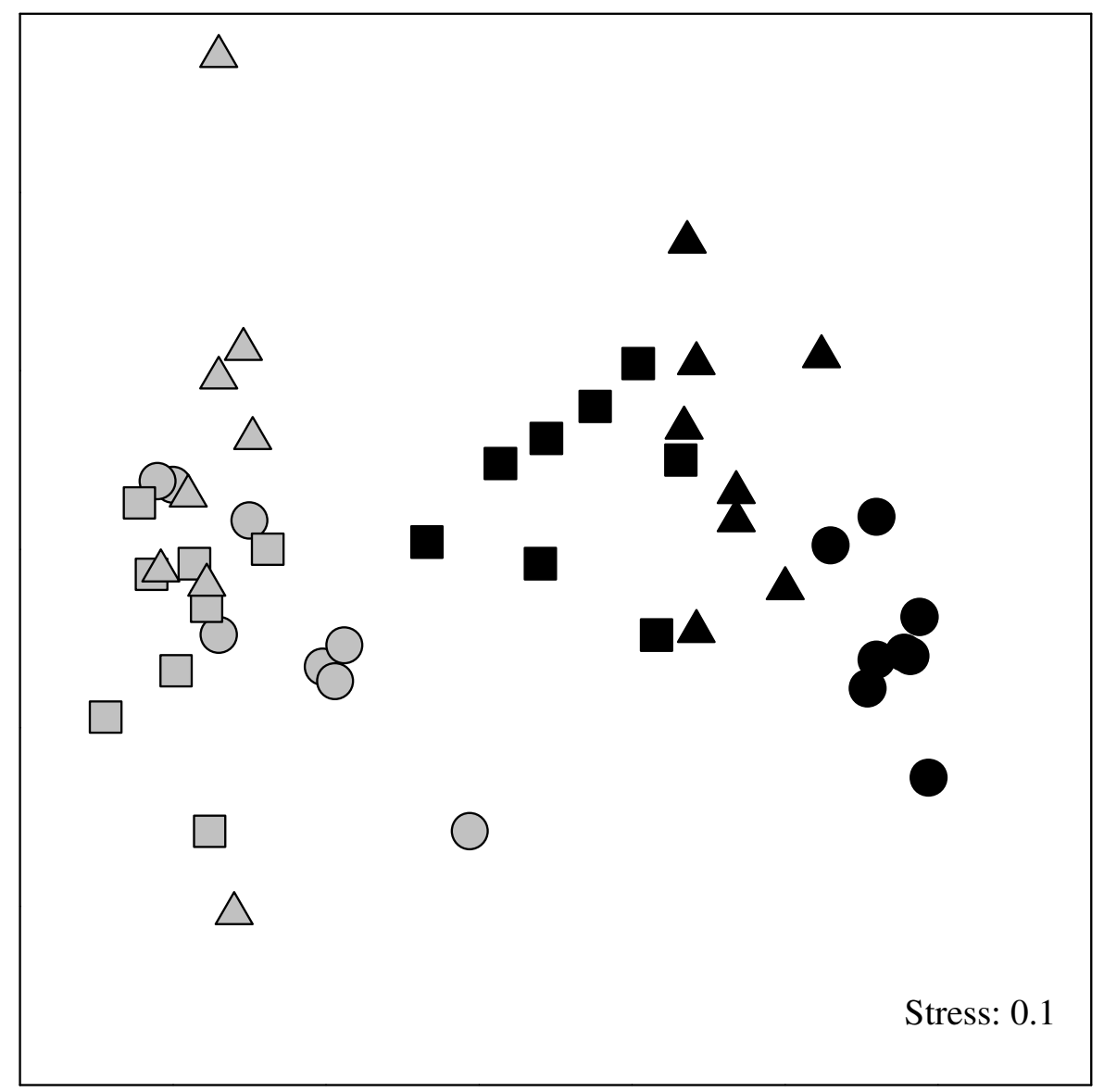

Fig. 4 Vaselli et al. 


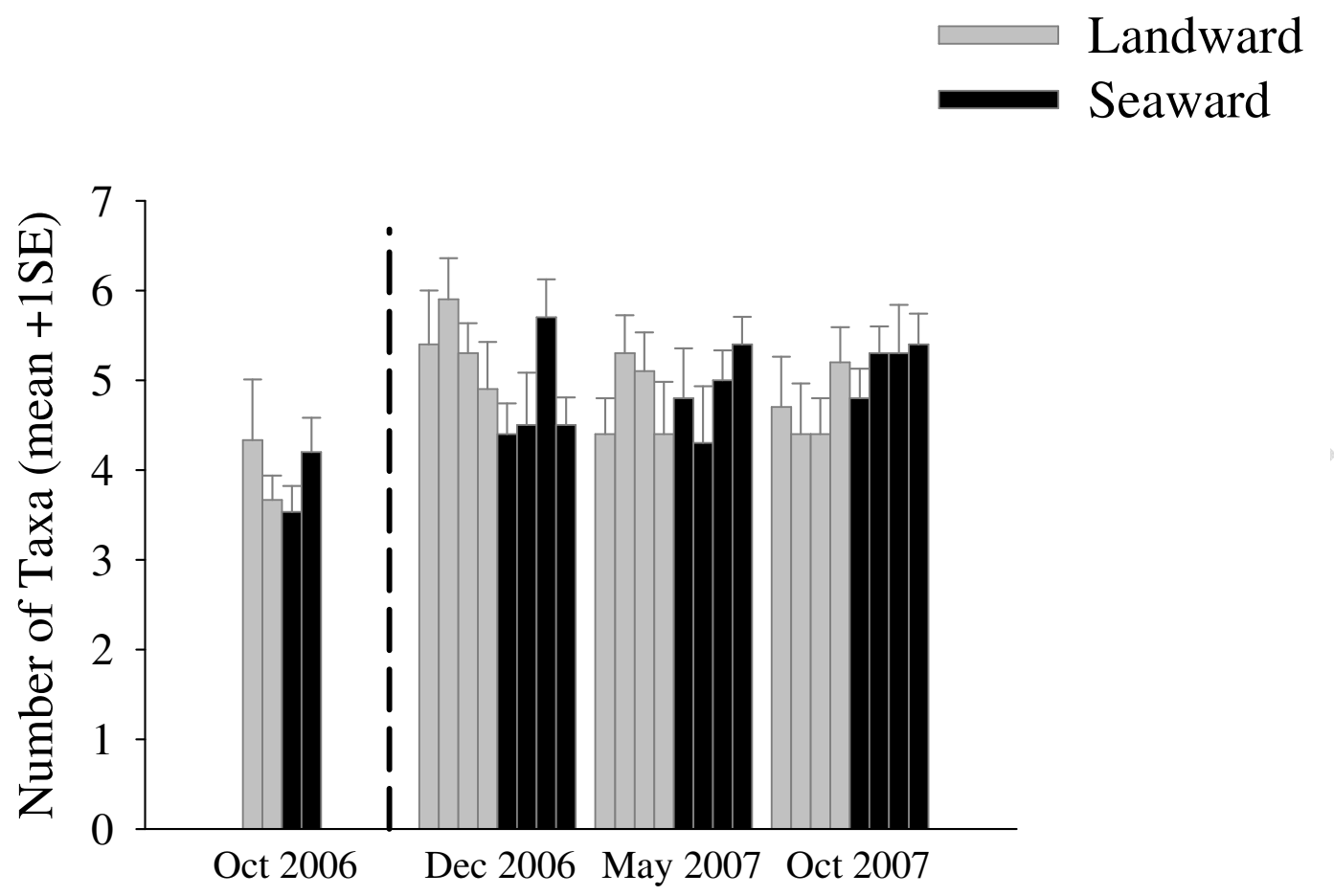

Fig. 5 Vaselli et al. 
VASELLI et al.
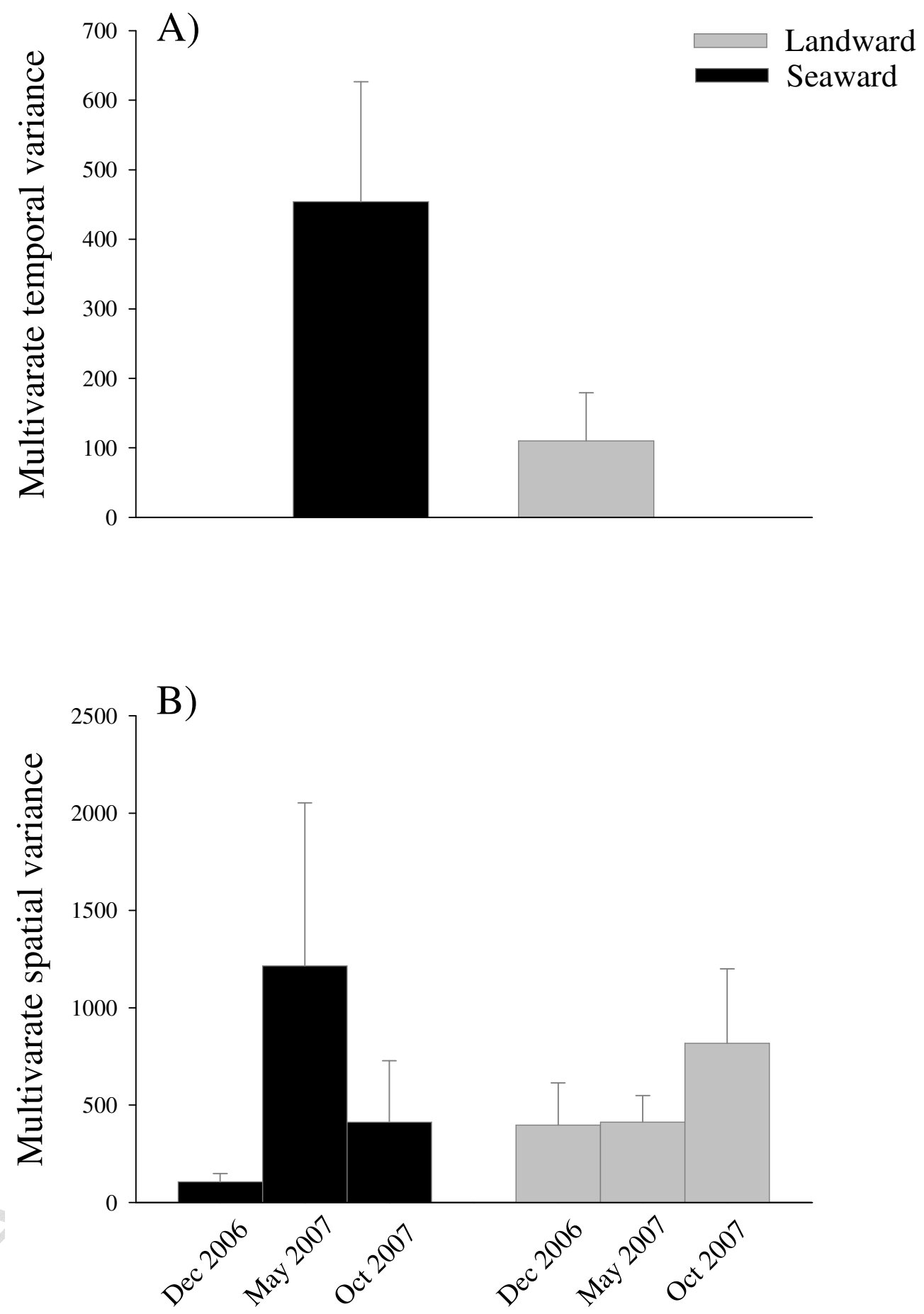

Fig. 6. Vaselli et al. 